Magdalena Hasiuk

\title{
Opowieść o dawnym życiu - Zły Dariusza Jeża i Grzegorza Kondrasiuka w reżyserii Łukasza Witt-Michałowskiego
}

\begin{abstract}
Streszczenie: Tekst prezentuje etapy pracy nad autobiograficznym przedstawieniem Zly na podstawie życia aktora, byłego recydywisty i gangstera Dariusza Jeża. Premiera spektaklu odbyła się 21 grudnia 2009 r. w Lublinie. Tekst wspólnie z aktorem opracowali dramaturg Grzegorz Kondrasiuk i reżyser przedstawienia Łukasz Witt-Michałowski. Na scenie obok Jeża wystąpili Przemysław Buksiński i Remigiusz Jankowski. Autobiograficzna opowieść Dariusza Jeża posiada moc kathartyczną i terapeutyczną zarówno dla wykonawcy, jak i dla widzów. Pozwala w symboliczny sposób włączyć aktora na powrót do społeczeństwa. Widzów natomiast pozostawia z pytaniem: czy jako członkowie tzw. normalnego społeczeństwa gotowi byliby do tak gruntownej przemiany i tak głębokiej spowiedzi, jakiej dokonał autor Złego?
\end{abstract}

Słowa kluczowe: teatr autobiograficzny, arteterapia, katharsis, resocjalizacja, teatr jako opowiadanie historii, Bertolt Brecht.

\section{The story of past life - Dariusz Jeż and Grzegorz Kondrasiuk's Bad directed by Łukasz Witt-Michałowski}

Summary: The text presents stages of the work over autobiographical performance Bad based on the life of Dariusz Jeż, the actor who used to be a gangster and recidivist. The premiere took place on 21 December 2009 in Lublin and the script was created through the cooperation of the lead with playwright Grzegorz Kondrasiuk and director Łukasz Witt-Michałowski. The drama alongside Da-

* Polska Akademia Nauk, Instytut Sztuki, 00-950 Warszawa, ul. Długa 26/28.

Badania, których wynikiem jest prezentowany tekst zostały sfinansowane ze środków Narodowego Centrum Nauki przyznanych w ramach finansowania stażu po uzyskaniu stopnia naukowego doktora na podstawie decyzji numer DEC-2012/04/S/HS2/00382. 
riusz Jeż features Przemysław Buksiński and Remigiusz Jankowski. The autobiographical account provides catharsis and therapeutic effect for the performers and the audience alike. In a symbolic way it allows the actors to re-enter the society whereas confronts the spectators with the question: Would we, as citizens conforming to social norms, be ready to undergo such a fundamental transformation and confess it as honestly and profoundly as the author of Bad did?

Keywords: autobiographical theatre, art therapy, catharsis, resocialization, storytelling, Bertolt Brecht.

Według francuskiego teoretyka teatru Patrice'a Pavisa - definicja autobiografii jako opowieści ,(zwykle prozą), której głównym tematem jest własne życie opowiadającego, a szczególnie rozwój jego osobowości” (Pavis, 1998, s. 509) - nie daje się zastosować do sztuki teatru. Tę bowiem stwarzają aktorzy przedstawiający na scenie postaci fikcyjne, a nie własne życie ani też życie autora. „Teatr autobiograficzny wydaje się, więc formą niemożliwą do realizacji” - konstatuje Pavis (ibidem). O ile jednak badacz jednoznacznie wyklucza z obszaru tego typu teatru monodramy oraz teksty dramatyczne o charakterze autobiograficznym, w których aktor jedynie przedstawia biografię autora, o tyle inaczej traktuje te przedstawienia, gdzie „aktor jest jednocześnie autorem wypowiedzi, w której mówi o sobie samym" (ibidem, s. 510).

Nie należy jednak zapominać, że aktor, jeśli nawet przedstawia i poddaje refleksji na scenie własną biografię, przeszłość i teraźniejszość, gra siebie, a nie jest sobą. I tutaj pojawia się kluczowe dla teatru rozdzielenie na realną osobę (posługującą się rzemiosłem aktorskim) i wykonawcę przedstawiającego postać. W przypadku spektaklu autobiograficznego dystans między tymi elementami może znacznie się skracać bądź być celowo wzmacniany. Przedstawienie autobiograficzne pozwala człowiekowi-aktorowi spojrzeć na siebie jako na odrębny, niejako obcy byt, uwolnić się od znanej i niekiedy bolesnej prawdy o sobie, by odkrywać prawdę nieznaną. To uwolnienie/odsłonięcie się aktora wzbudzić może podobny mechanizm $\mathrm{w}$ widzu. Wówczas zainspirowany opowieścią wykonawcy i on także gotów będzie, choć przez chwilę, popatrzeć na swoje życie z dystansem, by tak jak aktor stać się twórcą i obserwatorem jednocześnie własnego życia, znajomej, a zarazem fikcyjnej postaci. Dodatkowo, aktor biorący udział w przedstawieniu autobiograficznym postrzega i doznaje przemiany, której pod wpływem snucia opowieści na temat własnych doświadczeń, zgłębiania przeżyć i refleksji ulega on sam i historia jego życia. Wszystkie bowiem elementy tworzące sztukę teatru ,przeobrażaja się w coś innego niż są”, albowiem istotą tej sztuki ,jest przeobrażanie się tworzyw przed oczami widza, ich gra" (Skwarczyńska, 1953, s. 127).

Pavis zwraca ponadto uwagę, że „każde przedstawienie [nie tylko odgrywane przez aktora-autora na temat własnego życia - M. H.] jest dla aktora w jakiejś mierze 'autobiograficzne'", dlatego że ukazuje on swoje działania językowe i ge- 
styczne bezpośrednio przed widzem (Pavis, 1998, s. 510). Danuta Lalak podkreśla, że ,sposobem istnienia biografii jest przekaz językowy, ale też pozawerbalny - konstruowanie wizerunku i własnej cielesności” (Lalak, 2010, s. 21). W czasie spektaklu aktor nie tylko ,pisze” swoim ciałem jakąś część własnej biografii (Pavis, 1998, s. 510), ale także prezentuje część biografii wpisaną w swoje ciało. Całe ciało aktora (podobnie jak każdego człowieka) nie tylko ma pamięć zapisaną w subtelną tkankę systemu nerwowego, napięć mięśniowych, w ślady blizn i zniekształcenia, deformacje spowodowane przez wypadki losowe, choroby, proces starzenia się, ale „ono samo jest pamięcią” (Grotowski, 1999, s. 101). Przedstawienie autobiograficzne odgrywane przez aktora-autora „utkane” zostaje więc jakby z dwóch nici: wątku - opowieści o życiu wyartykułowanej przez słowa-dźwięki, gesty i ruchu oraz osnowy, którą jest sama obecność ciała i wnoszona przez nie pamięć.

Dariusz Jeż - obecnie aktor zawodowy lubelskiej Sceny Prapremier „InVitro", współpracujący z różnymi reżyserami (Joanna Lewicka, Paweł Passini) - w jednym z wywiadów telewizyjnych (http://www.youtube.com/watch?...) jasno przedstawił motywy, które skłoniły go do pracy nad przedstawieniem $Z$ ly $^{1}$ (reżyseria Łukasz Witt-Michałowski, premiera 21 grudnia 2009 r. w Lublinie). Chciał rozliczyć się z przeszłością, w inny sposób spojrzeć na siebie i swoje poprzednie - jak podkreślał - „ciekawe” życie, z którego nigdy później nie był dumny. Pragnął ostatecznie „domknąć pewne drzwi”. Od pierwszych chwil miał świadomość, że historia jego życia powinna posłużyć jako materiał do przedstawienia, w którym on także zagra. Tylko bowiem publicznie, obnażając na scenie mroki swojej biografii, w nowym miejscu i w nowej roli - jako aktor występujący na wolności, poza więziennymi murami - symbolicznie uwolni się od przeszłości. Planowane przedstawienie miało być spowiedzią dawnego gangstera, ujawnieniem piętna recydywisty, przy czym wpisana w nie funkcja kathartyczna (a może i resocjalizacyjna) służyć miała nie tylko autorowi/wykonawcy, ale także widzom. Dlatego też Zły w równym stopniu jest przykładem spektaklu terapeutycznego, jak i budzącego/budującego samoświadomość przedstawienia w stylu teatru Bertolda Brechta. Tekst, a także lubelskie przedstawienie stanowią jednocześnie dość rzadki w szeroko rozumianej biografistyce zapis życia przedstawiciela marginesu społecznego (por. Lalak, 2010, s. 114)². W pewnym momencie życia Dariusz Jeż znajdował się bowiem w takim właśnie miejscu.

Należy podkreślić, że pierwszym inicjatorem pracy nad przedstawieniem i dobrym duchem towarzyszącym Dariuszowi Jeżowi w ,powrocie do społeczeństwa" na wolności był reżyser teatralny, a prywatnie także przyjaciel Jeża Łukasz Witt-Michałowski. Panowie spotkali się w Areszcie Śledczym w Lublinie, gdzie

${ }^{1}$ W tytule przedstawienia łatwo dostrzec nawiązanie do powieści Leopolda Tyrmanda (Tyrmand, 2011). Przemysław Buksiński, odtwórca roli Młodego w przedstawieniu, nazywa spektakl „naszym lubelskim Ztym” (por. http://www.youtube.com/watch?...).

${ }^{2}$ Przykładem literackim prozatorskim jest Dziennik złodzieja Jeana Geneta (Genet, 2004). 
Witt-Michałowski miał na zlecenie lubelskiego Festiwalu Teatralnego Konfrontacje przygotować przedstawienie z więźniami. Jeż był jednym z nich. Witt-Michałowski wprowadził go w świat teatru, który niczym most pozwolił byłemu gangsterowi wrócić do „normalnego” życia.

Praca teatralna nad Złym rozpoczęła się kilka lat po wyjściu z więzienia od napisania tekstu. Z takim zamysłem Dariusz Jeż zwrócił się do człowieka pióra, Grzegorza Kondrasiuka. Praca nad tekstem pozwoliła narodzić się kolejnej przyjaźni. Tekst Złego powstawał w dialogu, podczas wielogodzinnych sesji, podczas których elementy autobiografii (Jeża) i biografii przyjaciela autorstwa Kondrasiuka płynnie się przenikały. Początkową formę zapisu można określić jako historię mówioną (oral history), obfitującą w bogactwo tematów, dygresji i anegdot. Kondrasiuk podkreślał jednak, że pomimo swobodnej formy, od początku wypowiedzi Dariusza Jeża podporządkowane były nadrzędnemu przesłaniu. Aktor, opowiadając swoje życie, „przeprowadzał bardzo precyzyjną misje” (http://www.youtube.com/ watch?...). Z licznych wielogodzinnych sesji-rozmów odbywanych w rozmaitych miejscach, o różnych porach dnia i nocy powstało kilkanaście godzin nagrań.

Tworzenie (uaktywnianie) biografii także w tym przypadku było „aktem komunikacyjnym i procesem społecznym" (Lalak, 2010, s. 83). Można zaryzykować twierdzenie, że zapisywanie, a następnie konstruowanie biografii/autobiografii Dariusza Jeża posiadało konsekwencje (zapewne nieco odmienne) dla dalszego życia nie tylko aktora, ale i wspierającego go dramaturga. Zdarzało się, że Kondrasiuka porażały usłyszane historie i zatrzymywał nagranie. Zadziwiony faktami prosił o powtórzenie relacji. Niektóre fragmenty „odchorowywał w swojej głowie”, mierzył się z tym, na ile może wniknąć w prywatność swojego rozmówcy. W przypadku Jeża tworzenie autobiograficznego dramatu odbywało się w chwili przekraczania ważnego progu - definitywnego zerwania z dawnym życiem przestępczym i gangsterką. Praca nad Zlym i sam spektakl utwierdzały i cementowały zmianę drogi życiowej. Stanowiły społeczną deklarację. Zapisanie własnej przeszłości, a następnie jej re-prezentowanie w ciągu licznych przedstawień (w tym także spektakli granych na festiwalu teatrów więziennych w Bogocie w Kolumbii jesienia 2012 r.) w wiecznym teatralnym teraz pozwoliło wyczerpać dawna czarną legendę aktora i jej „odejść”. Choć to oczywiste, że opowiedzenie „złej” historii swojego życia nie jest w stanie zmienić przeszłości, ale nieodwracalnie zmienia teraźniejszość, a co za tym idzie, zmienia wszystko, do czego jako ludzie mamy dostęp. Zmienia także przyszłość.

Kolejny etap pracy wiązał się z podjęciem dwóch decyzji: dotyczącej selekcji materiału (strukturyzacji doświadczeń), z myślą o ponadgodzinnym przedstawieniu (ostatecznie trwało ono ok. 1h 20'), oraz ze skonstruowaniem formy i z wyborem języka - zachowaniem lub odrzuceniem licznych wulgaryzmów. Pojawiły się także uwarunkowania innego rodzaju. Kondrasiuk musiał zmienić lub ukryć wiele szczególów opowiadanej historii z powodu trwających procesów sądowych, z tego też powodu nie mógł sięgnąć do niektórych opowieści. $Z$ doświadczenia życia mającego cha- 
rakter „całościowy, substancjalny i ciągły” (Lalak, 2010, s. 14) zostały wybrane tylko te aspekty, które łączyły się z mroczną przeszłością byłego kryminalisty - prowadziły do niej, zapowiadały ją, stanowiły jej istotę i konsekwencje. Obecność w historii innych osób została mocno ograniczona. Z wielości własnych ,Ja postrzeganych [nie tylko] z perspektywy różnych ról społecznych i, jak zauważa Goffman, paradoksalnie składających się na absolutną pojedynczość życia" (por. Goffman, 2005, s. 101) Jeż ujawnił jedynie te związane z tożsamością społeczną przestępcy. Dokonał zawężającej i modulującej jego osobiste doświadczenia selekcji. Można byłoby przypuszczać, że historia jego życia składała się tylko z takich niechlubnych zachowań. Trzy dni po premierze 24 grudnia 2009 r. w „Dzienniku Wschodnim” opublikowany został duży materiał autorstwa Agnieszki Mazuś zapisany w pierwszej osobie i poświęcony życiu aktora Dariusz Jeż: Byłem zły (http://www.dziennikwschodni.pl/...). Z tekstu wyłaniają się przemilczane w spektaklu wątki biograficzne Dariusza Jeża. Widzimy go nie tylko jako młodego ulicznika, gangstera czy recydywistę, ale także jako samodzielnego chłopca z biednej, rozbitej rodziny (,Bardzo wcześnie musiałem [...] ugotować, posprzątać” (ibidem)), zakochanego mężczyznę („Ożeniłem się z dziewczyną, którą zobaczyłem na schodach. Miłość od pierwszego wejrzenia naprawdę istnieje" (ibidem)), kompetentnego pracownika, męża i ojca troszczącego się o byt rodziny nawet za cenę emigracji (,Szukałem chleba w Holandii, Francji, Hiszpanii [...]. Po dwóch latach stwierdziłem, że żona żyje na jakimś tam poziomie, ale nie widzimy się" (ibidem)), człowieka, który nieodwracalnie utracił to, co w życiu najcenniejsze (,W sumie $\mathrm{w}$ więzieniach $\mathrm{i}$ aresztach przesiedziałem prawie pięć lat. Dziś przeraża mnie to. Te kilka lat mogłem spędzić z żoną. Bardzo ją kochałem i myślałem, że będzie żyła wiecznie” (ibidem)). W Zlym brakuje tego bogactwa. Swoisty „retusz” obejmuje całą jaśniejszą stronę osoby. Pozostaje historia awansującego na drodze przestępczej cinkciarza, oszusta i gangstera. Przedstawienie, podzielone na trzynaście wyodrębnionych i niezależnych obrazów ${ }^{3}$ wpisanych w ramę (jakby z innego porządku) wyznaczoną przez ekspozycję i finał, stanowi wyznanie grzechów. Objawia kolejne stopnie wkraczania w świat przestępczy, trzy odsiadki (jak upadki Chrystusa pod krzyżem) i próbę samobójczą. Czyni to precyzyjnie, bez zbędnego epatowania okrucieństwem, z dystansem, niekiedy i z humorem. Zabiegi te dodatkowo wzmacnia język wulgarny i poetycki zarazem.

Dialogiczna konstrukcja tekstu - warunek tradycyjnego dramatu - w Ztym została poszatkowana i wpisana w obszerny monolog głównego bohatera, stanowiący przykład teatru postrzeganego ,jako opowiadanie historii” (storytelling):

STARY: „Najdłużej w życiu nie spałem trzynaście dni. Jak mój adwokat powiedział, że wychodzę [...]. I tak czekam, w nocy siedzę, oglądam telewizję. Trzecia, czwarta, piąta noc. Mówię chłopakom, że nie śpię. Nie wierzą, zaczęli mnie pilnować na zmianę, zakładać się.

${ }^{3}$ Tytuły kolejnych obrazów to: Fiedia, Zomowcy, Kosmos, Padlina, Rubikon, Samurajski sposób, Henio Główka, Prosperita, Pierwszy zjazd, Złoty czas, Drugi zjazd, Złoty strzał, Trzeci zjazd (Jeż, Kondrasiuk, 2009). 
Okazało się, że naprawdę nie śpię. Szósta, siódma, ósma. Nie wiem, co się ze mną dzieje, w ogóle się nie męczę. Każdy mięsień napięty, zmysły wyostrzone, słyszę najmniejszy szmer na korytarzu [...]. I tak dotargałem do trzynastu nocy. A po trzynastu nocach wyszedłem" (Jeż, Kondrasiuk, 2009).

Cały spektakl niczym strumień pamięci głównego bohatera łączy i na nowo splata dawne sytuacje, doznania i wrażenia. Dariusz Jeż grany w przedstawieniu przez dwóch różniących się wiekiem i posturą aktorów, najpierw jako opowiadacz pewnych sytuacji, a później także ich uczestnik i przewodnik po kolejnych wydarzeniach, wprowadza w nie publiczność i je odgrywa. Znajduje się jednocześnie w środku i na zewnątrz przywoływanej opowieści. Tę podwójność ról (narratora i aktora) i związany z nią dystans dodatkowo wzmacniało rozbicie głównego bohatera na dwóch wykonawców Starego (Dariusz Jeż) i Młodego (Przemysław Buksiński), którzy w przełomowych momentach, dwukrotnie w przedstawieniu - w zapowiedzi akcji i tuż przed jej finałem - wypowiadają wspólny tekst. W obu przypadkach dotyczył on Fiedi, ważnej dla Jeża osoby, mężczyzny, który wprowadził go w świat przestępczy:

STARY/MŁODY (razem): „Tak mi się ubzdurało, że [Fiedia] to mój starszy brat [...].

MŁODY/STARY (razem): Fiedia, który zmarł wskutek wylewu trzy miesiące później”.

Zastosowana wymiana ról między Starym i Młodym, a także inne zabiegi formalne służą zmianie perspektywy patrzenia na historię życia bohatera. Jednocześnie czynią z widzów obserwatorów jego dawnych działań i słuchaczy jego aktualnej opowieści. Spektakl teatralny staje się momentem spotkania z niechlubną historią jednostki, ale i chwilą społecznego pojednania z człowiekiem przez wiele lat wykluczonym z tzw. normalnego społeczeństwa. Finał, w którym Dariusz Jeż mówi osobisty monolog o swoim ludzkim odrodzeniu dzięki grze w więziennym teatrze, kończył się słowami skierowanymi do widzów: „Wasz świat jest inny, wy jesteście szczerzy, prawdziwi, dobrzy, lojalni, uczciwi...” (Jeż, Kondrasiuk, 2009). Słowa te wprowadzały swoisty efekt obcości, nadawały bowiem przedstawianym dotychczas na scenie zdarzeniom znamion czegoś zaskakującego, czegoś, co nie jest w prosty sposób naturalne (Brecht, 1975, s. 62).

Danuta Lalak zwróciła uwagę na to, że: „Każdy człowiek u kresu pisania autobiografii powinien spróbować odpowiedzieć na pytanie kim jestem?" (Lalak, 2010, s. 98). W biograficznym artykule opublikowanym w przywołanym już „Dzienniku Wschodnim”, a towarzyszącym premierze Złego, Dariusz Jeż wyznał, że nigdy tego nie wiedział („Nigdy nie wiedziałem, kim jestem. Jakąś hybrydą, mutantem, zjawiskiem" (http://www.dziennikwschodni...)). Nieprzypadkowo jednak jako człowiek i aktor zmierzył się z formą teatru autobiograficznego. Patrice Pavis wśród trzech form przedstawień autobiograficznych obok opowieści o własnym życiu i wyznań intymnych umieścił właśnie gry z tożsamością. „Teatr autobiograficzny staje się próbą określenia własnej tożsamości: kulturowej, 
etnicznej, społecznej" - pisał Pavis (Pavis, 1998, s. 511). Czy Zły pomógł Dariuszowi Jeżowi w określeniu własnej tożsamości, trudno jednoznacznie orzec. Z pewnością via negativa, jaką ,przemierzył” twórca w tym przedstawieniu, by oczyścić siebie z dawnych i niechlubnych doświadczeń, stanowi jeden ze sposobów przybliżających aktora do własnej esencji.

Jednocześnie jest coś niepokojącego dla widza w finale przedstawienia w reżyserii Łukasza Witt-Michałowskiego. Efekt obcości, jakim się ono kończy, stanowi także coś innego niż wezwanie do odpowiedzi na pytanie o tożsamość aktora, byłego recydywisty. To dziwne wrażenie prowokuje widzów z tzw. normalnego społeczeństwa do stawiania pytań o własną tożsamość. Czy rzeczywiście „nasz świat jest inny, jesteśmy szczerzy, prawdziwi, dobrzy, uczciwi...”? I przede wszystkim, czy gotowi bylibyśmy do takiej przemiany i takiej autobiograficznej spowiedzi, jakiej dokonał autor Złego?

Pracę Dariusza Jeża, Grzegorza Kondrasiuka i Łukasza Witt-Michałowskiego nad przedstawieniem Zły można zestawić z praktyką stosowaną przez terapeutkę, pisarkę i reżyserkę Dagnę Ślepowrońską, która w Kobiecym Ośrodku Teatralnym działającym przy Centrum Praw Kobiet w Warszawie w pracy z kobietami, które doświadczyły przemocy, stworzyła własną metodę opartą na połączeniu psychoterapii i twórczości teatralnej. Nazwała ją „teatrem obrzędowym” i scharakteryzowała w następujący sposób:

Chodzi mi $[\ldots]$ o terapię, która jest sztuką [...] o terapię, która lecząc daje jednocześnie produkt czysto artystyczny. Z perspektywy jednostkowej rozszerza się na perspektywę społeczną. Od zmiany osobistej przechodzi do dialogu ze społecznością, zachowując jednocześnie osobisty, intymny, ale też transcendentny charakter dzieła sztuki (Ślepowrońska, 2010, s. 9).

Terapeutka, nawiązując do struktury obrzędów przejścia obecnych w wielu kulturach, w procesie uzdrawiania sytuacji kobiet wyróżniła trzy fazy: wyłączenia - polegającego na wyjściu z roli ofiary przemocy (tak się dzieje w momencie przystąpienia do pracy), oczekiwania - obejmującego psychoterapię i włączenia - podczas którego panie „wracają” do społeczeństwa na nowych prawach. Tę ostatnią fazę stanowi przygotowywany przez nie spektakl. Rozszerzenie praktyki terapeutycznej o doświadczenia teatralne okazało się w pewnym momencie dla Ślepowrońskiej koniecznością. Przedstawienie utrwala bowiem zmianę statusu osoby krzywdzonej, a jednocześnie pomaga systemowi społecznemu przyjąć tę przemianę. Często bowiem „życie”, ,system” nie są gotowe na zaakceptowanie ludzkiego uzdrowienia (por. Ślepowrońska, 2010, s. 18). Jednocześnie praca twórcza z reguły przynosi nieoczekiwane uzupełnienie terapii. „Proces artystyczny pozwala odkryć to, co do tej pory było zakryte" (ibidem, s. 58). A praca nad spektaklem staje się tą częścią terapii, w której panie wyzwalają się z ról pacjentek.

Mimo wielu zasadniczych różnic (Zły nie był ukoronowaniem terapii zespołowej, Dariusz Jeż nie był ofiarą przemocy, najważniejszy cel przedstawienia sta- 
nowił efekt artystyczny, nie terapeutyczny) przedstawienie w reżyserii Witt-Michałowskiego w stosunku do głównego aktora Dariusza Jeża stało się rodzajem „teatru obrzędowego". Było realnym działaniem utrwalającym zmianę statusu osoby resocjalizowanej, a jednocześnie skutecznie pomogło systemowi społecznemu przyjąć tę indywidualną, napełniającą olbrzymią nadzieją przemianę. I społecznie cieszyć się nią.

\section{Literatura}

Brecht B., 1975, Wartość mosiądzu, przekład zespołowy, WAiF, Warszawa.

Genet J., 2004, Dziennik złodzieja, przeł. P. Kamiński, Wydawnictwo Zielona Sowa, Kraków.

Goffman E., 2005, Piętno. Rozważania o zranionej tożsamości, przeł. A. Dzierżyńska, J. Tokarska-Bakir, Gdańskie Wydawnictwo Psychologiczne, Gdańsk.

Grotowski J., 1999, Ćwiczenia, [w:] idem, Teksty z lat 1965-1969, red. J. Degler, Z. Osiński, Wiedza o Kulturze, Wrocław, s. 87-110.

http://www.youtube.com/watch?v=20dLN2B8kyE [dostęp 10.02.2013].

http://www.dziennikwschodni.pl/apps/pbcs.dll/article?AID=/20091224/MAGAZYN/957397347 [dostęp 19.07.2013].

Jeż D., Kondrasiuk G., 2009, Zły, mpis.

Lalak D., 2010, Życie jako biografia. Podejście biograficzne w perspektywie pedagogicznej, Wydawnictwo Akademickie „Żak”, Warszawa.

Mazuś A., 2009, Dariusz Jeż: Byłem zły, „Dziennik Wschodni”, 24 grudnia, http://www.dziennikwschodni.pl/apps/pbcs.dll/article? AID=/20091224/MAGAZYN/957397347 [dostęp 19.07.2013].

Pavis P., 1998, Słownik terminów teatralnych, przeł., oprac. i uzup. S. Świontek, Zakład Narodowy im. Ossolińskich, Wrocław, Warszawa, Kraków.

Skwarczyńska S., 1953, O rozwoju tworzywa stownego i form podawczych w dramacie, [w:] eadem, Studia i szkice literackie, Warszawa, s. 123-150.

Ślepowrońska D., 2010, Teatr psychoterapii. O praktykowaniu teatru obrzędowego, Centrum Praw Kobiet, Warszawa.

Tyrmand L., 2011, Zły, MG Wydawnictwo, Warszawa. 